Article

\title{
Bread Wheat Quality: Some Physical, Chemical and Rheological Characteristics of Syrian and English Bread Wheat Samples
}

\author{
Abboud Al-Saleh ${ }^{1}$ and Charles S. Brennan ${ }^{2, *}$
}

1 Food Science Department, Faculty of Agriculture, Al Furat University, Deir-Ezzor, Syria; E-Mail: abbalsaleh@yahoo.co.uk

2 Department of Wine, Food and Molecular Biosciences, Lincoln University, Lincoln 7647, Canterbury, New Zealand

* Author to whom correspondence should be addressed; E-Mail: Charles.brennan@lincoln.ac.nz; Tel.: +64-3-321-8236.

Received: 21 September 2012; in revised form: 1 November 2012 / Accepted: 8 November 2012 / Published: 22 November 2012

\begin{abstract}
The relationships between breadmaking quality, kernel properties (physical and chemical), and dough rheology were investigated using flours from six genotypes of Syrian wheat lines, comprising both commercially grown cultivars and advanced breeding lines. Genotypes were grown in 2008/2009 season in irrigated plots in the Eastern part of Syria. Grain samples were evaluated for vitreousness, test weight, 1000-kernel weight and then milled and tested for protein content, ash, and water content. Dough rheology of the samples was studied by the determination of the mixing time, stability, weakness, resistance and the extensibility of the dough. Loaf baking quality was evaluated by the measurement of the specific weight, resilience and firmness in addition to the sensory analysis. A comparative study between the six Syrian wheat genotypes and two English flour samples was conducted. Significant differences were observed among Syrian genotypes in vitreousness $(69.3 \%-95.0 \%)$, 1000-kernel weight $(35.2-46.9 \mathrm{~g})$ and the test weight $(82.2-88.0 \mathrm{~kg} / \mathrm{hL})$. All samples exhibited high falling numbers (346 to $417 \mathrm{~s}$ for the Syrian samples and 285 and $305 \mathrm{~s}$ for the English flours). A significant positive correlation was exhibited between the protein content of the flour and its absorption of water $\left(r=0.84^{* *}\right)$, as well as with the vitreousness of the kernel $(r=0.54 *)$. Protein content was also correlated with dough stability $\left(r=0.86^{* *}\right)$, extensibility $\left(r=0.8^{* *}\right)$, and negatively correlated with dough weakness $(r=-0.69 * *)$. Bread firmness and dough
\end{abstract}


weakness were positively correlated $\left(r=0.66^{* *}\right)$. Sensory analysis indicated Doumah-2 was the best appreciated whilst Doumah 40765 and 46055 were the least appreciated which may suggest their suitability for biscuit preparation rather than bread making.

Keywords: bread wheat; kernel characteristics; flour; dough; bread quality; sensory analysis

\section{Introduction}

Bread wheat is an important crop worldwide especially in the Mediterranean basin. During the last ten years Syrian bread wheat production constituted more than half of Syria's total wheat production [1]. This level of production can be explained by the importance of bread in the Syrian diet. Bread is considered the staple food for most people and consumed on a daily basis with two-layered bread in the most common form of bread in Syria and its neighbouring countries such as Lebanon, Jordan and Iraq. However, due to changes in dietary habits other forms of bread, such as Western style bread, can be found on the Syrian market and its consumption is increasing. The Western forms of bread are generally made in small bakeries using local flours; however no research has been carried out to explore the suitability of Syrian genotypes for the production of Western style bread. Current Syrian breeding programs are attempting to satisfy demand for bread making flours. For instance, researchers have tried to use the kernel physical traits (vitreousness, hardness, and specific weight), chemical characteristics of the flour (protein, ash, starch) and rheological properties of the dough (elasticity, resistance) to predict the quality of bread [2] or other cereal products $[3,4]$.

The baking potential of wheat flours is influenced by many factors, most notably protein content [5-8]. Protein content is in turn influenced mainly by nitrogen fertilization, while the protein quality is determined primarily by the wheat genotype [3,4]. On the other hand, both the quality and the content of the wheat protein are affected by the climatic conditions during wheat maturation [9-11]. Vitreousness is considered to be related to the endosperm microstructure whereas hardness is suggested to influence the adhesion forces between starch granules and protein matrix [12]. Using election microscopy techniques and chemical analysis, a strong relationship between vitreousness and protein content was illustrated. Consequently, vitreousness can be used to predict the quality of kernel wheat end-uses [4,13]. Many studies investigating bread wheat baking performance have addressed protein properties, with particular emphasis on gluten strength. Differences in baking quality among cultivars have been related to differences in gluten composition, particularly to the high molecular weight glutenin subunits [7,14-17]. However, the separation of protein fractions, especially gliadins and glutenins, is still difficult due its dependency on the extraction conditions, which minimize the possibility to predict the baking quality in correlation with the flour characteristics [14,16].

In recent years, various researchers have attempted to avoid the baking tests by predicting bread quality through prediction models in which combination of measurements made from grain, flour and dough were used. For instance when trying to predict loaf volume, Miller [18] included glutenin quantity, gliadins percentage, flour colour grade, protein content, glutenin elastic modulus, farinograph 
water absorption, particle size index, moisture content, and the ratio of HMW to LMW glutenins in his equation for optimal flour content. Lee et al. [19] included in their prediction equation grain protein content, hardness index, mixograph water absorption and peak height, and break flour extraction and managed to achieve an $R^{2}=0.70$ in terms of equation to product quality. Dowell et al. [20] combined grain, flour, and dough quality measurements into models to predict bread quality. They concluded that loaf volume and baking mix time, and water absorption could be predicted with $R^{2}$ of $0.78-0.93$. The three previous works cited indicate the difficulty in developing models to predict wheat baking performance, and confirms it is still necessary to perform baking tests in order to achieve a reliable evaluation.

The purpose of the present study was to investigate the major physical, chemical and rheological characteristics of some widely cultivated varieties in addition to some of those in the process of accreditation. The impact of these characteristics on the quality of the produced bread was also studied. For reliable evaluation of the ability of the Syrian genotypes for Western style bread preparation, a comparative study with some commonly used English flour was conducted. Consumer judgment is the most valuable tool in food quality assessment; therefore, a sensory analysis for bread quality evaluation was performed using a panel of assessors who regularly consume the product.

\section{Experimental Section}

\subsection{Materials}

Six Syrian bread wheat genotypes, Sham-6, Sham-8, Bouhouth-8, Doumah-3, Doumah-40765 and Doumah-46055 were selected. These genotypes are recommended for sowing in irrigated areas. Doumah 40765 and Doumah 46055 genotypes are awaiting certification. Samples were provided from the Ministry of Agriculture, the General Commission for Scientific Agricultural Research, Deir Ezzor Research Station, which is located in the east of Syria. Genotypes were grown at the same location and under the same agro ecological conditions in the crop year 2009. The English flour samples were obtained from the commonly used flour in the market (Smith Flour Mills, Worksop, UK).

\subsection{Physical Analyses}

\subsubsection{Test Weight}

Test weight was determined using the approved method of the American Association of Cereal Chemists 55-10 [21], and the results were reported in $\mathrm{kg} / \mathrm{hL}$. Damaged kernels were separated from the sound kernels for all the samples for the thousand kernel weight test, thousand grains were counted and weighed [3]. The degree of virtuousness was determined manually by sorting kernels, clean samples were used and 100 kernels were examined visually and separated into two groups, kernels free of starchy or speckled appearance called vitreous and those of starchy appearance named mealy $[3,4]$. Each sample was tested in triplicate. 


\subsubsection{Chemical Analyses}

Water content of the kernels and the flour was determined by the approved AACC method 44-15 [21]. Protein content was conducted using the Kjedahl method and expressed using the conversion factor $N \times 5.7$ [22]. Falling number was determined using the approved AACC method 56-81 [21]. Ash content was determined using the approved method 08-01 [21]. Results were expressed at a $14 \%$ water content basis and each sample was tested in triplicate.

\subsubsection{Colour}

The colour of the flour and the breads was assessed using a Datacolour Spectra (Datacolour International Lawrenceville, NJ, USA). In the Datacolour spectrophotometer SF600 Plus, the colour of a sample is denoted by the three dimensions, $L^{*}, a^{*}$ and $b^{*}$. The $L^{*}, a^{*}$ and $b^{*}$ readings were treated using the software Colortools V3.1. The $L *$ value gives a measure of the lightness of the product colour from 100 for perfect white to zero for black as the eye would evaluate it. The redness + /greenness - and the yellowness $+/$ blueness ${ }^{-}$are denoted by the $a *$ and $b *$ values respectively. The colour of each sample was measured three times.

\subsubsection{Flour Yield}

Flour production was achieved by cleaning the samples using sieves. Samples were tempered to $14 \%$ water content overnight (based on previous trial work, data not shown). Moistened samples were milled into flour using a Brabender Quadrumat Junior Experimental Mill (Brabender Co. Duisburg, Germany). Flour extraction was expressed on a total product basis; its rate was $72 \%$.

\subsubsection{Bread Preparation}

Bread preparation was conducted using a recipie and a protocol supplied by an industrial partner (not identified by request). The recipe of dough preparation was as shown in Table 1. The flour (Smith Flour Mills, Worksop, UK), the improver (Diamond British Arkady, UK) and the white shortening (Promaline, Vandemoortele, Hounslow, UK) were placed in the mixing bowl (Hobart A120, Hobart MFG Co., Troy, OH, USA). The dehydrated yeast (Craft Bake, DCL, UK) was added to the warm water and then added to the flour and mixed on speed 1 for 1 min followed by $10 \mathrm{~min}$ at speed 2 . Then the other ingredients were added. The dough was divided into $300 \mathrm{~g}$ pieces rounded and left to rest under a cover for $10 \mathrm{~min}$. The dough was moulded into a loaf shape and placed in tins. The tins were then put in the prover at $42{ }^{\circ} \mathrm{C}$ and $80 \% \mathrm{RH}$ until the dough level reaches the top level of tin. Dough pieces were transferred to the oven and baked for $25 \mathrm{~min}$ at the temperature of $230{ }^{\circ} \mathrm{C}$. The bread loaves were cooled and packed for testing. In total 10 breads were produced for analysis. 
Table 1. Formulation of breads.

\begin{tabular}{ccc}
\hline Constituent & Quantity $(\mathbf{g})$ & \% of Total Weight \\
\hline Flour & 1500 & 58.55 \\
Yeast & 30 & 1.17 \\
Salt & 27 & 1.05 \\
Diamond improver & 30 & 1.17 \\
White shortening & 75 & 2.93 \\
Water & 900 & 35.13 \\
\hline
\end{tabular}

\subsubsection{Bread Dough Characteristics}

The Extensibility of dough was studied using a texture analyzer (TA-XT plus, Stable Micro Systems, Godalming, Surrey, UK) calibrated for a load cell of $30 \mathrm{~kg}$. The Extensibility of dough was determined by the tensile test using the Kieffer rig (setting: pre-test speed, $2.0 \mathrm{~mm} / \mathrm{s}$; test speed, $3.3 \mathrm{~mm} / \mathrm{s}$; post test speed, $10.0 \mathrm{~mm} / \mathrm{s}$; distance, $75 \mathrm{~mm}$; trigger force, auto-5 g; data rate acquisition, 200 point per second). More than 15 strips of dough were tested from each batch. Water absorption of flour was evaluated using the farinograph apparatus. Rheological properties of dough (development time, stability, mixing time, weakness and resilience) were determined according to the approved AACC method 54-21.01 [21].

\subsubsection{Bread Quality Evaluation}

Bread firmness was determined using a texture analyzer (TA-XT Plus, Stable Micro Systems, Godalming, Surrey UK), calibrated for a load cell of $30 \mathrm{~kg}$. Bread loaves were sliced mechanically into $12.5 \mathrm{~mm}$ slice thickness using Greaf bread slicing machine (Graef, Bradford, UK). Two slices were stacked together for each test, discarding two end slices of the loaf. Bread firmness was measured with a probe $25 \mathrm{~mm}$ in diameter and at $40 \%$ compression. Firmness was defined as the maximum force obtained during compression. Bread firmness and resilience (ability to recover from compression) were measured on three successive days using the method described as AACC Standard Method 74-09 [21]. Breads were stored in sealed plastic bags at $25^{\circ} \mathrm{C}$.

\subsubsection{Loaf Volume}

Loaf volume was measured by small seeds displacement method [23]. A container was used to measure the volume using small grains. Rapeseeds were poured into the container of known volume until the bottom was covered. The loaf was placed inside the container which was then filled to the top with more seeds. The extra rapeseeds, which equal the loaf volume, were measured in a graduated cylinder. The specific volume of the loaf was calculated using the following equation (1):

$$
\text { Specific volume }\left(\mathrm{cm}^{3} / \mathrm{g}\right)=\frac{\text { loaf volume }}{\text { loaf weight }}
$$




\subsubsection{Sensory Analysis}

Sensory evaluation for bread was carried out under white light at room temperature in individual sensory booths at the Food Technology Laboratory, Hollings Faculty, MMU, Manchester, UK. The sensory laboratory conforms to ISO standard guidelines for the design of test rooms (ISO standard 8589,1988 ) and ASTM's physical requirements guidelines for sensory evaluation laboratories (ASTM 913, 1986). Bread was evaluated by generic descriptive analysis in accordance to Lawless and Heymann [24]. Ten experienced people were selected to assess the attributes of bread. Prior to sensory evaluation, the panellists were given the necessary training about the descriptors. For evaluation, samples were presented in 3-digit codes. Assessors evaluated colour, appearance, manual \& oral texture, and flavour using a 10-point scale (Table 2). Data were recorded using the FIZZ computerised system version 1.20 (Biosystemes, Couternon, France).

\subsubsection{Statistical Analyses}

A total of 10 loaves of bread were made. All the experiments were replicated in triplicate unless otherwise stated. The coefficient of variability of all the tests was lower than $10 \%$. Analysis of variance (ANOVA) and the linear regressions followed by Tukey's test in addition to the correlations between factors were performed using SPSS 16.0 (SPSS Inc., Chicago, IL, USA). All the calculations were done at the significance level of $p<0.05$. Correlation coefficients were run between the different variables using Microsoft Excel at the significance level of $p<0.05,0.01,0.005$.

Table 2. Descriptive vocabulary and definitions used by assessors to evaluate bread.

\begin{tabular}{|c|c|}
\hline Attribute & Definition \\
\hline \multicolumn{2}{|l|}{ Appearance } \\
\hline Crust colour & Degree of colour darkness in the crust ranging from pale to dark brown \\
\hline Crust colour & Degree of colour darkness in the crumb ranging from creamy to white \\
\hline Crumb appearance & Degree of porosity and its uniformity from non uniform to uniform \\
\hline \multicolumn{2}{|l|}{ Odour } \\
\hline Yeasty & Odour associated with aromatic exchange from yeast fermentation \\
\hline Grainy & An aromatic impression of cereal derived products like wheat, barley and corn \\
\hline \multicolumn{2}{|l|}{ Texture } \\
\hline Manual & Force required snapping sample by hand \\
\hline Oral & Force required biting completely through sample placed between the molars \\
\hline \multicolumn{2}{|l|}{ Flavour } \\
\hline Sweet & Fundamental taste sensation of which sucrose is typical \\
\hline Salt & Fundamental taste sensation elicited by sodium chloride \\
\hline Sour & Fundamental taste sensation evoked by acids \\
\hline
\end{tabular}

\section{Results and Discussion}

\subsection{Physical Properties}

Physical characteristics such as vitreousness, kernel weight and test weight of the Syrian genotypes were determined to assess their contribution to the quality of the prepared bread. Vitreousness is 
an important factor in the determination of the quality of the wheat type because it reflects the texture of the endosperm and consequently the end use of the wheat $[4,13,25]$. Results showed that Bouhouth- 8 had the highest percentage of vitreousness (95\%) among all the Syrian genotypes (Table 3). There were no significant differences between the Doumah varieties, which varied from $69.3 \%$ to $76.6 \%$, or the Sham genotypes. The 1000 kernel weight values showed a significant difference between most of the genotypes with values varying from $46 \mathrm{~g}$ (Doumah-2) to $35.2 \mathrm{~g}$ (Sham 6). Doumah's genotypes yielded high 1000-kernel weight values (Table 3). Test weight values were generally high and showed significant differences between genotypes, for instance $82 \mathrm{~kg} / \mathrm{hL}$ for Sham- 6 to $88 \mathrm{~kg} / \mathrm{hL}$ for Doumah-2. Doumah-40765 and Doumah-46055 (the latter are in the process of accreditation by the Syrian ministry of agriculture whereas Doumah-2 is already certified). The measurement of the water content showed slight differences among the genotypes. The low values reflect the drought of the environment during the period of harvesting in the eastern part of Syria where the genotypes were grown. The variations of values for the studied characteristics of the genotypes are likely to be the results of genotypic variation [26], as the agronomic conditions of the trial plots were as uniform as possible with regards to the field plot experiments.

Table 3. Selected physical characteristics of Syrian wheat samples.

\begin{tabular}{ccccc}
\hline Genotype & $\begin{array}{c}\text { Vitreousness } \\
\mathbf{( \% )}\end{array}$ & $\begin{array}{c}\text { Kernel weight } \\
(\mathbf{g})\end{array}$ & $\begin{array}{c}\text { Test Weight } \\
\mathbf{( k g / h L )}\end{array}$ & $\begin{array}{c}\text { Water content } \\
(\mathbf{\%})\end{array}$ \\
\hline Doumah 2 & $71.33 \mathrm{ab}$ & $45.96 \mathrm{~d}$ & $88.01 \mathrm{~d}$ & $5.98 \mathrm{a}$ \\
Doumah 40765 & $69.33 \mathrm{a}$ & $45.62 \mathrm{~d}$ & $84.62 \mathrm{bc}$ & $5.94 \mathrm{a}$ \\
Doumah 46055 & $76.67 \mathrm{abc}$ & $44.43 \mathrm{c}$ & $85.13 \mathrm{bc}$ & $6.01 \mathrm{a}$ \\
Sham 6 & $81.67 \mathrm{bc}$ & $35.26 \mathrm{a}$ & $82.24 \mathrm{a}$ & $6.43 \mathrm{c}$ \\
Sham 8 & $86.67 \mathrm{~cd}$ & $37.31 \mathrm{~b}$ & $85.80 \mathrm{c}$ & $6.28 \mathrm{bc}$ \\
Bouhouth 8 & $95.00 \mathrm{~d}$ & $36.02 \mathrm{a}$ & $84.20 \mathrm{~b}$ & $6.15 \mathrm{ab}$ \\
\hline
\end{tabular}

Values within columns with different letters are significantly different at $p<0.05$.

Vitreousness was negatively correlated with the kernel weight and the test weight, the correlation values were $r=-0.79 * *$ and $r=-0.35$ respectively. There was a significant positive correlation between the kernel weight and the test weight $(r=0.62 * *)$ and a negative effect of the water content on the test weight of all the genotypes $(r=-51 *)$ (Table 4$)$.

Table 4. Correlation coefficients between physical characteristics of genotypes.

\begin{tabular}{cccc}
\hline & Kernel Weight & Test Weight & Water Content \\
\hline Vitreousness & $-0.794 * *$ & -0.347 & $0.544 *$ \\
Kernel weight & & $0.619 * *$ & $-0.831 * *$ \\
Test weight & & $-0.509 *$ \\
\hline \multicolumn{4}{c}{$* 0.05 ; * *<<0.01 ; * * p<0.005}$.
\end{tabular}

\subsection{Chemical Properties}

A range of chemical properties of the Syrian and the English flour samples are presented in Table 5. The nutritional content of breads is related to the chemical composition of the bread, hence protein content and starch composition are of importance when considering the dietary impact of breads. 
Some significant differences were observed in the protein content of all the samples. For instance, among the Syrian samples Sham-6 had the highest protein content while Doumah-40765 had the lowest value. The falling number of the Syrian samples varied between $345 \mathrm{~s}$ for Sham- 6 and $417 \mathrm{~s}$ for Doumah-2 which reflect a low $\alpha$-amylase activity, while the English samples had lower falling number values around $300 \mathrm{~s}$ (Table 5).

Protein content and vitreousness were correlated positively $(r=0.54 *)$, while a negative significant correlation between the protein content and the kernel weight was noticed ( $r=-0.8 * *)$ (Table 4). A previous study on some Syrian durum wheat genotypes showed similar conclusions [26]. Results showed no correlation existed between the test weight and the protein content. A similar observation was mentioned by El-Khayat et al. [4]. The ash values for the Syrian samples did not show any significant difference among them and varied from $0.63 \%$ to $0.72 \%$ (on a dry basis), however there was a slight difference compared to the English samples $(0.87 \%$ and $0.97 \%)$. Significant variations in the degree of water absorption of the flour samples were observed, varying from $56.3 \%$ for Doumah-40567 to $64 \%$ for the strong English sample. A correlation was noticed between the water absorption of the flour samples and its protein contents $(r=0.84 * *)$ (Table 6). Concerning the colour of the flour, no significant difference was detected among most of the samples (Table 5). The colour of the flour samples were bright where $L *$ values exceeded 92 for all of them except the English strong flour which is likely related to its high protein content (13.69\%). Negative correlations were observed between the flour colour $L *$ and the ash and protein with correlation values $r$ of $-0.62 * *$ and $-0.78 * *$ respectively. This observation can be explained by the negative effect of the increase of both the protein and ash on the flour brightness. This conclusion can be enhanced by the negative correlation between the flour colour value $L *$ and the water absorption. The redness values of the flour samples $a *$ did not show significant difference, while the yellowness values $b *$ varied from 8.57 for the weak English flour to 11.55 for Sham- 8 which is due to more likely to the difference of pigments among samples, the negative significant correlation between $b *$ values and ash values enhance the previous conclusion $(r=-0.49 *)$.

Table 5. Chemical characteristics of wheat flour samples.

\begin{tabular}{|c|c|c|c|c|c|c|c|c|}
\hline Genotype & $\begin{array}{c}\text { Ash } \\
(\mathrm{g} / 100 \mathrm{~g})\end{array}$ & $\begin{array}{l}\text { Protein } \\
(\mathrm{g} / \mathbf{1 0 0} \mathrm{g})\end{array}$ & $\begin{array}{c}\text { Falling } \\
\text { Number } \\
\text { (sec) }\end{array}$ & $\begin{array}{c}\text { Water } \\
\text { Content } \\
(\mathrm{g} / \mathbf{1 0 0} \mathrm{g})\end{array}$ & $\begin{array}{c}\text { Water } \\
\text { Absorption } \\
\text { (g/100 g) }\end{array}$ & $\begin{array}{c}\text { Flour } \\
\text { Colour } L\end{array}$ & $\begin{array}{c}\text { Flour } \\
\text { Colour } a\end{array}$ & $\begin{array}{c}\text { Flour } \\
\text { Colour b }\end{array}$ \\
\hline Doumah 2 & $0.677 \mathrm{a}$ & $10.82 \mathrm{c}$ & $417.33 \mathrm{e}$ & $14.5 \mathrm{e}$ & $56.45 \mathrm{a}$ & $93.14 \mathrm{~b}$ & $1.41 \mathrm{a}$ & $10.28 \mathrm{bcd}$ \\
\hline Doumah 40765 & $0.717 \mathrm{a}$ & $9.52 \mathrm{a}$ & $379.66 \mathrm{~d}$ & $13.9 \mathrm{~d}$ & $56.30 \mathrm{a}$ & $93.16 \mathrm{~b}$ & $1.15 \mathrm{a}$ & $9.46 \mathrm{abc}$ \\
\hline Doumah 46055 & $0.690 \mathrm{a}$ & $10.06 \mathrm{~b}$ & $351.66 \mathrm{c}$ & $13.0 \mathrm{~b}$ & $59.40 \mathrm{c}$ & $92.52 \mathrm{~b}$ & $1.56 \mathrm{a}$ & $10.46 \mathrm{cde}$ \\
\hline Sham 6 & $0.630 \mathrm{a}$ & $11.75 \mathrm{~d}$ & $345.66 \mathrm{c}$ & $12.9 \mathrm{~b}$ & $60.10 \mathrm{~d}$ & $92.95 \mathrm{~b}$ & $1.58 \mathrm{a}$ & $9.47 \mathrm{abc}$ \\
\hline Sham 8 & $0.723 \mathrm{a}$ & $11.02 \mathrm{c}$ & $372.33 \mathrm{~d}$ & $13.1 \mathrm{~b}$ & $61.40 \mathrm{e}$ & $92.05 \mathrm{~b}$ & $1.75 \mathrm{a}$ & $11.55 \mathrm{e}$ \\
\hline Bouhouth 8 & $0.687 \mathrm{a}$ & $11.10 \mathrm{c}$ & $375.33 \mathrm{~d}$ & $13.5 \mathrm{c}$ & $60.30 \mathrm{~d}$ & $92.20 \mathrm{~b}$ & $1.68 \mathrm{a}$ & $11.31 \mathrm{de}$ \\
\hline Strong English & $0.973 \mathrm{~b}$ & $13.69 \mathrm{e}$ & $285.66 \mathrm{a}$ & $11.1 \mathrm{a}$ & $64.05 \mathrm{f}$ & $89.93 \mathrm{a}$ & $1.10 \mathrm{a}$ & $9.18 \mathrm{ab}$ \\
\hline Weak English & $0.873 \mathrm{~b}$ & $9.77 \mathrm{ab}$ & $305.33 \mathrm{~b}$ & $11.1 \mathrm{a}$ & $58.05 \mathrm{c}$ & $92.97 \mathrm{~b}$ & $1.30 \mathrm{a}$ & $8.57 \mathrm{a}$ \\
\hline
\end{tabular}




\subsection{Dough Properties}

Flour samples showed considerable variations in the dough characteristics, where the mixing time varied from $1.5 \mathrm{~min}$ for the English weak samples to $3 \mathrm{~min}$ for Sham-6 and Bouhouth-8. The characteristics of the dough of both Doumah 40567 and 46055 were practically identical (Table 7). Dough samples also showed a wide range of dough stability, which varied from $1.5 \mathrm{~min}$ for Doumah 46055 to 8.4 min for the English strong sample. Doumah's samples exhibited significant differences in weakness while Sham-6 had the least weakness value (52 BU) among the Syrian samples. Resistance values varied from $11.38 \mathrm{~g}$ to $39.34 \mathrm{~g}$ (Table 7) with Syrian dough samples showing less resistance than the English doughs. A negative correlation between dough mixing time and ash content was noticed $(r=-0.69)$, while a positive correlation existed between the dough stability and the protein content of the samples $\left(r=0.86^{* *}\right)$ and also with water absorption of the flour $\left(r=64^{* *}\right)$ (Table 6). A negative correlation between dough weakness and protein content existed $(r=-69 * *)$, in addition to a logic negative correlation between dough weakness and its stability $(r=-0.8)$. Dough extensibility was positively correlated with protein $(r=0.8 * *)$ and also with the water absorption of the flour and the mixing time and resistance with $\mathrm{r}$ values of $0.69 * *, 0.83^{* *}$ and $0.48^{* *}$ respectively. On the other hand, dough extensibility was negatively correlated with weakness $(r=-0.78)$ (Table 6). Other researchers have reported that increased protein content generally increases dough extensibility due to the complex nature of the gliadin and glutenin proteins in forming a hydrated gluten matrix permitting controlled extension and elasticity of the dough [27-31]. 
Table 6. Correlation coefficients between characteristics of all samples.

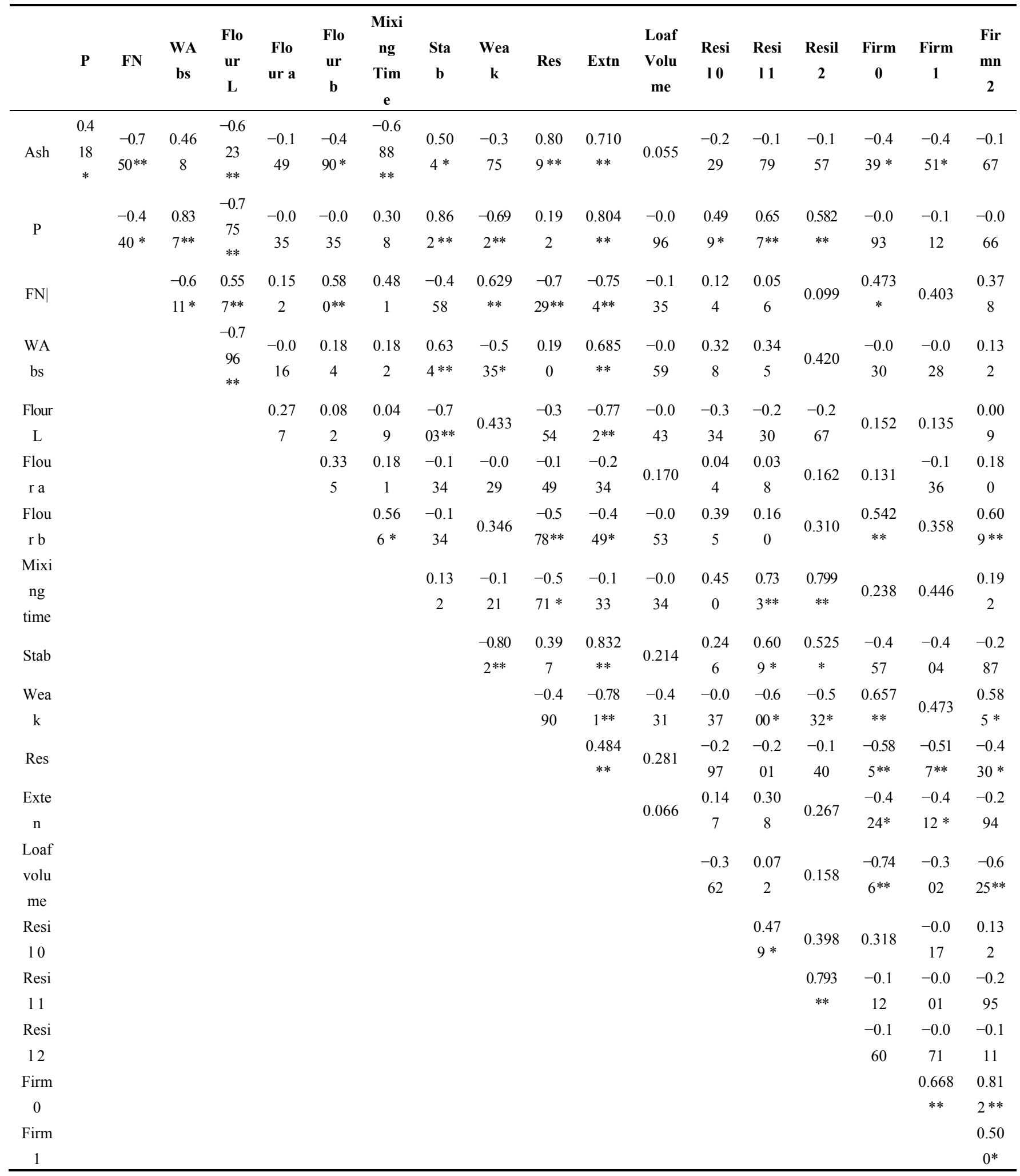

P: protein; FN: falling number; WAbs: water absorption; Flour L: light colour of flour; Flour a: red colour of flour; Flour b: yellow colour of flour; Stab: Stabilisation; Res: resistivity; Extn: extensibility; Resil 0, 1, 2: Resilience of sliced bread at day 0, day 1, day 2; Firm $0,1,2$ : Firmness of sliced bread day 0 , day 1 , day $2 ; * p<0.05, * * p<0.01 ; * * * p<0.005$ 
Table 7. Characteristics of the dough samples.

\begin{tabular}{cccccc}
\hline Genotype & $\begin{array}{c}\text { Mixing Time } \\
(\mathbf{m i n})\end{array}$ & $\begin{array}{c}\text { Stability } \\
(\mathbf{m i n})\end{array}$ & $\begin{array}{c}\text { Weakness } \\
(\mathbf{B U})\end{array}$ & $\begin{array}{c}\text { Resistance } \\
(\mathbf{g})\end{array}$ & $\begin{array}{c}\text { Extensibility } \\
(\mathbf{m m})\end{array}$ \\
\hline Doumah 2 & $2.5 \mathrm{c}$ & $4.0 \mathrm{~cd}$ & $92.5 \mathrm{bc}$ & $15.57 \mathrm{c}$ & $12.62 \mathrm{a}$ \\
Doumah 40765 & $2.0 \mathrm{~b}$ & $2.5 \mathrm{ab}$ & $95.0 \mathrm{bc}$ & $11.38 \mathrm{a}$ & $12.22 \mathrm{a}$ \\
Doumah 46055 & $2.0 \mathrm{~b}$ & $1.5 \mathrm{a}$ & $105.0 \mathrm{c}$ & $12.35 \mathrm{ab}$ & $12.77 \mathrm{a}$ \\
Sham 6 & $3.0 \mathrm{~d}$ & $3.5 \mathrm{bc}$ & $52.5 \mathrm{ab}$ & $11.77 \mathrm{ab}$ & $25.89 \mathrm{c}$ \\
Sham 8 & $2.5 \mathrm{c}$ & $2.5 \mathrm{~b}$ & $105.0 \mathrm{c}$ & $13.55 \mathrm{~b}$ & $12.52 \mathrm{a}$ \\
Bouhouth 8 & $3.0 \mathrm{~d}$ & $5.0 \mathrm{~d}$ & $60.0 \mathrm{ab}$ & $18.50 \mathrm{~d}$ & $17.07 \mathrm{ab}$ \\
Strong & $2.0 \mathrm{~b}$ & $8.4 \mathrm{e}$ & $30.0 \mathrm{a}$ & $30.55 \mathrm{e}$ & $62.50 \mathrm{~d}$ \\
Weak & $1.5 \mathrm{a}$ & $3.0 \mathrm{bc}$ & $67.5 \mathrm{abc}$ & $39.34 \mathrm{f}$ & $21.86 \mathrm{bc}$ \\
\hline
\end{tabular}

Values within columns with different letters are significantly different at $p<0.05$.

\subsection{Bread Quality}

\subsubsection{Functional Properties}

The samples did not show significant differences in the specific volume of bread loaf which varied from 3.48 for Sham-6 to 3.73 for Bouhouth-8. All Syrian genotypes showed a similar ability to produce bread when compared to the English. The resilience 0 values did not show significant differences between samples except Doumah-40567 and the weak English flour sample which had low values compared to the others (Table 8). The resilience on day 2 (resilience-1) showed significant differences between samples where three groups can be distinguished. This difference between samples was magnified during the third day (resilience-3) values. A decrease of resilience values in relation with time are obvious (Table 8). The firmness 0 values showed three groups significantly different where Sham- 8 had the highest value 965.9 g. The day-three firmness values (firmness-2) were not significantly different for all samples except for Sham-8 where its firmness value reached $1234.2 \mathrm{~g}$ (Table 8). The resilience of the bread has been shown previously to be related to the protein content of the flour and doughs $[7,11]$, this can be supported by the positive correlations between these values observed in Table 6.

Table 8. Characteristics of the bread samples.

\begin{tabular}{cccccccc}
\hline \multirow{2}{*}{ Genotype } & $\begin{array}{c}\text { Specific } \\
\text { Volume }\end{array}$ & $\begin{array}{c}\text { Resilience 0 } \\
(\mathbf{g})\end{array}$ & $\begin{array}{c}\text { Resilience 1 } \\
(\mathbf{g})\end{array}$ & $\begin{array}{c}\text { Resilience 2 } \\
(\mathbf{g})\end{array}$ & $\begin{array}{c}\text { Firmness 0 } \\
(\mathbf{g})\end{array}$ & $\begin{array}{c}\text { Firmness 1 } \\
(\mathbf{g})\end{array}$ & $\begin{array}{c}\text { Firmness 2 } \\
\text { (g) }\end{array}$ \\
\hline Doumah-2 & $3.530 \mathrm{a}$ & $62.94 \mathrm{~b}$ & $52.48 \mathrm{~b}$ & $48.59 \mathrm{bcd}$ & $720.34 \mathrm{~b}$ & $822.68 \mathrm{ab}$ & $961.55 \mathrm{a}$ \\
Doumah-40765 & $3.630 \mathrm{a}$ & $45.46 \mathrm{a}$ & $45.46 \mathrm{a}$ & $41.44 \mathrm{a}$ & $590.11 \mathrm{ab}$ & $833.09 \mathrm{ab}$ & $899.62 \mathrm{a}$ \\
Doumah-46055 & $3.565 \mathrm{a}$ & $64.06 \mathrm{~b}$ & $44.68 \mathrm{a}$ & $42.66 \mathrm{ab}$ & $697.58 \mathrm{~b}$ & $775.68 \mathrm{a}$ & $956.10 \mathrm{a}$ \\
Sham-6 & $3.545 \mathrm{a}$ & $58.80 \mathrm{~b}$ & $58.80 \mathrm{c}$ & $52.37 \mathrm{de}$ & $689.94 \mathrm{~b}$ & $929.45 \mathrm{ab}$ & $852.70 \mathrm{a}$ \\
Sham-8 & $3.485 \mathrm{a}$ & $56.92 \mathrm{~b}$ & $46.07 \mathrm{a}$ & $45.07 \mathrm{abc}$ & $965.90 \mathrm{c}$ & $1072.26 \mathrm{~b}$ & $1234.72 \mathrm{~b}$ \\
Bouhouth-8 & $3.735 \mathrm{a}$ & $58.06 \mathrm{~b}$ & $58.06 \mathrm{bc}$ & $55.91 \mathrm{e}$ & $527.04 \mathrm{a}$ & $795.99 \mathrm{ab}$ & $837.85 \mathrm{a}$ \\
Strong & $3.600 \mathrm{a}$ & $61.51 \mathrm{~b}$ & $54.82 \mathrm{bc}$ & $50.02 \mathrm{cde}$ & $503.50 \mathrm{a}$ & $670.50 \mathrm{a}$ & $854.97 \mathrm{a}$ \\
Weak & $3.640 \mathrm{a}$ & $46.09 \mathrm{a}$ & $42.32 \mathrm{a}$ & $41.20 \mathrm{a}$ & $498.04 \mathrm{a}$ & $714.63 \mathrm{a}$ & $798.37 \mathrm{a}$ \\
\hline
\end{tabular}


The daily results for bread resilience were positively correlated with the protein content of the samples with significant correlation values of $0.5^{*}, 0.7^{* *}$ and $0.6^{* *}$ respectively (Table 6). Another significant correlation with the flour mixing time was noticed, where correlation values were $0.45 *$, $0.73 *$ and $0.79 * *$. Bread firmness during the three day time was positively correlated, where the correlation value $(r)$ between firmness 1 and 2 was $0.67^{* *}$, and $0.81 * *$ with firmness 3 , while the correlation value between firmness 2 and 3 was $0.5 *$ (Table 6). A positive correlation was detected between firmness in its three stages and dough weakness with $r$ values as follows: $0.66 * *$ for day-one firmness, $0.47 *$ for day two firmness and $0.59 *$ for day-three firmness, in addition to significant negative correlations with dough resistance where $\mathrm{r}$ values were $-0.59 * *,-0.52 * *$ and $-0.43 *$ for the three successive days (Table 6). The correlation values illustrate the effect of the protein content on the quality of the bread and these results are in general agreement with numerous studies highlighted the close relationship between bread-making quality of the wheat flour and the grain protein content $[8,10,32,33]$.

\subsubsection{Sensory Analysis}

The results of the sensory analysis of the bread samples are presented in Table 9. Although the results were generally not significantly different, the results revealed trends amongst the bread. For instance Doumah-40765 had the highest score for the colour of the crust (5.77) among all samples whereas the weak English sample had the lowest value (2.58) (Table 9). Similarly there was a trend concerning the colour of the crumb with Sham-8 preferred the most (5.97) while the strong English flour was the least appreciated (2.18). Doumah-2 had the best crumb appearance (7.19) while Doumah-40765 was the least appreciated (2.62). Concerning the odour of the bread (yeasty and grainy) and its taste (sweetness, saltiness and sourness) in addition to crumb hardness, no significant differences were noticed among samples (Table 9).

Table 9. Bread sensory analysis.

\begin{tabular}{|c|c|c|c|c|c|c|c|c|c|c|c|}
\hline Genotype & $\begin{array}{l}\text { Crust } \\
\text { Colour }\end{array}$ & $\begin{array}{l}\text { Crumb } \\
\text { Colour }\end{array}$ & $\begin{array}{l}\text { Crumb } \\
\text { Appear }\end{array}$ & $\begin{array}{l}\text { Odour } \\
\text { Yeasty }\end{array}$ & $\begin{array}{l}\text { Odour } \\
\text { Grainy }\end{array}$ & $\begin{array}{c}\text { Crumb } \\
\text { Hardness }\end{array}$ & $\begin{array}{c}\text { Crumb } \\
\text { Adhesion }\end{array}$ & Sweetness & Saltiness & Sourness & $\begin{array}{c}\text { Bread } \\
\text { Overall }\end{array}$ \\
\hline Doumah 2 & $5.18 \mathrm{~b}$ & $5.41 \mathrm{~b}$ & $7.19 \mathrm{~b}$ & $4.02 \mathrm{a}$ & $3.85 \mathrm{a}$ & $6.84 \mathrm{a}$ & $6.67 \mathrm{~b}$ & $2.58 \mathrm{a}$ & $3.51 \mathrm{a}$ & $3.61 \mathrm{a}$ & $6.47 \mathrm{~b}$ \\
\hline Doumah 40765 & $5.77 \mathrm{~b}$ & $4.21 \mathrm{ab}$ & $2.62 \mathrm{a}$ & $4.70 \mathrm{ab}$ & $4.68 \mathrm{a}$ & $4.25 \mathrm{a}$ & $4.48 \mathrm{ab}$ & $2.88 \mathrm{a}$ & $2.84 \mathrm{a}$ & $3.65 \mathrm{a}$ & $2.91 \mathrm{a}$ \\
\hline Doumah 46055 & $4.89 \mathrm{~b}$ & $4.33 \mathrm{ab}$ & $4.24 \mathrm{ab}$ & $5.15 \mathrm{ab}$ & $4.17 \mathrm{a}$ & $3.75 \mathrm{a}$ & $5.27 \mathrm{ab}$ & $2.69 \mathrm{a}$ & $3.33 \mathrm{a}$ & $4.08 \mathrm{a}$ & $3.63 \mathrm{ab}$ \\
\hline Sham 6 & $4.94 \mathrm{~b}$ & $5.97 \mathrm{~b}$ & $4.70 \mathrm{ab}$ & $3.84 \mathrm{a}$ & $4.69 \mathrm{a}$ & $5.29 \mathrm{a}$ & $5.85 \mathrm{ab}$ & $3.16 \mathrm{a}$ & $3.32 \mathrm{a}$ & $3.50 \mathrm{a}$ & $5.70 \mathrm{ab}$ \\
\hline Sham 8 & $4.35 \mathrm{~b}$ & $3.57 \mathrm{ab}$ & $5.53 \mathrm{ab}$ & $6.30 \mathrm{~b}$ & $4.18 \mathrm{a}$ & $4.39 \mathrm{a}$ & $5.87 \mathrm{ab}$ & $3.78 \mathrm{a}$ & $3.46 \mathrm{a}$ & $3.35 \mathrm{a}$ & $4.45 \mathrm{ab}$ \\
\hline Bouhouth 8 & $5.66 \mathrm{~b}$ & $4.83 \mathrm{~b}$ & $7.13 \mathrm{~b}$ & $4.65 \mathrm{ab}$ & $4.44 \mathrm{a}$ & $6.12 \mathrm{a}$ & $5.13 \mathrm{ab}$ & $2.62 \mathrm{a}$ & $3.61 \mathrm{a}$ & $3.74 \mathrm{a}$ & $5.55 \mathrm{ab}$ \\
\hline Strong & $5.56 \mathrm{~b}$ & $2.18 \mathrm{a}$ & $5.33 \mathrm{ab}$ & $5.43 \mathrm{ab}$ & $4.59 \mathrm{a}$ & $5.73 \mathrm{a}$ & $5.06 \mathrm{ab}$ & $3.43 \mathrm{a}$ & $3.06 \mathrm{a}$ & $3.53 \mathrm{a}$ & $4.65 \mathrm{ab}$ \\
\hline Weak & $2.58 \mathrm{a}$ & $4.12 \mathrm{ab}$ & $6.01 \mathrm{~b}$ & $6.29 \mathrm{~b}$ & $4.11 \mathrm{a}$ & $6.42 \mathrm{a}$ & $2.61 \mathrm{a}$ & $2.98 \mathrm{a}$ & $3.50 \mathrm{a}$ & $4.65 \mathrm{a}$ & $4.35 \mathrm{ab}$ \\
\hline
\end{tabular}

Values within columns with different letters are significantly different at $p<0.05$.

As can be seen in Table 8, the crumb of Doumah-2 was appreciated the most by the assessors in terms of crumb adhesion in the mouth (6.67), on the other hand, the weak English sample was the most sticky when chewed between molars which gains a poor response from the assessors (2.61). The other 
samples gained similar response from the panellists, where no significant differences were observed (Table 9). The results of bread overall rating revealed three distinct groups significantly different, where Doumah-2 was the most appreciated (6.47). The results for the sensory properties of the bread provide interesting preliminary findings.

\section{Conclusions}

The results of our research illustrate variations between Syrian genotypes in vitreousness, kernel weight and test weight; differences were also noticed in protein content, falling number, flour water absorption and the colour of the flour in all Syrian and English samples. Experimental lines, Doumah-40765 and Doumah-46055 exhibited reduced vitreousness and protein content compared to any of the other genotypes. Samples showed clear differences in dough and bread characteristics (resilience and firmness). The differences in physical, chemical and rheological characteristics between samples did not give significant variations in specific loaf volume, but those differences affected the quality of the loaf. Bread sensory analysis clearly demonstrated the effect of the kernel physical characteristics, flour chemical traits and the dough rheology on bread quality. Colour, appearance and texture were the major factor in bread evaluation. Results proved conclusively the validity of the Syrian genotypes for Western style bread making which is not one of the mostly commonly produced bread on the Syrian market. The Syrian variety Doumah-2 was the most appreciated among all samples, while Doumah 40765 and 46055 were the least appreciated by the assessors which may suggest their suitability for biscuit preparation rather than bread making. Correlation analyses confirmed the importance of the vitreousness, protein content and the rheological traits of dough on the quality of bread especially the resilience and firmness. It is common in breeding programs to assess the suitability of grain solely on the properties of the raw material. In this study, sensory analysis was prioritized to assess bread quality rather than relying on judging the quality of the final product merely through quantitative evaluation of kernel and flour characteristics.

\section{Acknowledgments}

The research was undertaken with the support from Al Furat University, Syria and with the laboratory help of Manchester Metropolitan University, UK.

\section{Conflict of Interest}

The authors declare no conflict of interest.

\section{References}

$1 \quad$ World Grain Statistics; International Grains Council: London, UK, 2007.

2 Poblaciones, M.J.; Lopez-Bellido, L.; Rafael, J. Field estimation of technological bread-making quality in wheat. Field Crops Res. 2009, 112, 253-259.

3 Samaan, J.; El-Khayat, G.H.; Manthey, F.; Fuller, M.; Brennan, C.S. Durum wheat quality: II The relationship of kernel physicochemical composition to semolina quality and end product utilisation. Int. J. Food Sci. Technol. 2006, 41, 47-55. 
4 El-Khayat, G.H.; Samaan, J.; Manthy, F.A.; Fuller, M.P.; Brennan, C.S. Durum wheat quality I: Some physical and chemical characteristics of Syrian durum wheat genotypes. Int. J. Food Sci. Technol. 2006, 41, 22-29.

5 MacRitchie, F. Evaluations of contributions from wheat protein fractions to dough mixing and bread making. J. Cereal Sci. 1987, 6, 259-268.

6 Graybosch, R.; Peterson, J.C.; Moore, K.J.; Stearns, M.; Grant, D.L. Comparative effects of wheat flour protein, lipid and pentosan composition in relation to baking and milling quality. Cereal Chem. 1993, 70, 95-101.

7 Weegels, P.L.; Hamer, H.J.; Schofield, J.D. Functional properties of wheat glutenin. J. Cereal Sci. 1996, 23, 1-17.

8 Huebner, F.R.; Bietz, J.A.; Nelson, T.; Bains, S.G.; Finney, P.L. Soft wheat quality as related to protein composition. Cereal Chem. 1999, 76, 650-655.

9 Johnson, J.A.; Khan, M.; Sanchez, C.R. Wheat cultivars, environment and bread-making quality. Cereal Sci. Today 1972, 17, 323-326.

10 Randall, P.J.; Moss, H.J. Some effects of temperature regime during grain filling on wheat quality. Aust. J. Agric. Res. 1990, 41, 603-617.

11 Johansson, E.; Svensson, G. Variation in bread making quality: Effect of weather parameters on protein concentration and quality in some Swedish wheat cultivars grown during the period 1975-1996. J. Sci. Food Agric. 1998, 78, 109-118.

12 Greffeuille, V.; Abecassis, J.; Rousset, M.; Oury, F.; Faye, A.; Lullien-Pellerin, A. Grain characterization and milling behavior of near-isogenic lines differing by hardness. Theor. Appl. Genet. 2006, 114, 1-12.

13 Alsaleh, A.; Gallent, D.J. Rheological and ultrastuctural studies of wheat kernel behaviour under compression as a function of water content. Food Microstruct. 1985, 4, 199-211.

14 Preston, K.R.; Lukow, O.M.; Morgan, B. Analysis of relationships between flour quality properties and protein fractions in a world wheat collection. Cereal Chem. 1992, 69, 560-567.

15 Shrewry, P.R.; Halford, N.G.; Tatham, A.S. High molecular weight subunits of wheat glutenin. J. Cereal Sci. 1992, 15, 105-120.

16 Schofield, J.D. Wheat proteins: Structure and functionality in milling and bread making. In Wheat, Production, Properties and Quality; Bushuk, W., Rasper, V.P., Eds.; Chapman \& Hall: London, UK, 1994; pp.: 73-106.

17 Wieser, H.; Zimmermann, G. Importance of amount and proportions of high molecular weight subunits of glutenin for wheat quality. Eur. Food Res. Technol. 2000, 210, 324-330.

18 Miller, S.J. The Development of Near-Infrared (NIR) Spectroscopy Calibrations for the Prediction of Wheat and Flour Quality, Project Report No. 310. Home-Grown cereal authority (HGCA): Kenilworth, UK, 2003.

19 Lee, K.M.; Shrroyer, J.P.; Herrman, T.J.; Lingenfelser, J. Blending hard white wheat to improve grain yield and end-use performances. Crop Sci. 2006, 46, 1124-1129.

20 Dowell, F.E.; Maghirang, E.B.; Pierce, R.O.; Lookhart, G.L.; Bean, S.R.; Xie, F.; Caley, M.S.; Wilson, J.D.; Seabourn, B.W.; Ram, M.S.; et al. Relationship of bread quality to kernel, flour, and dough properties. Cereal Chem. 2008, 85, 82-91. 
21 Approved Methods of the AACC, Methods 55-10, 44-15, 56-81B, 76-13, 76-21, 10th ed.; American Association of Cereal Chemists: St Paul, MN, USA, 2000.

22 Official Methods of Analysis; Williams S., Ed.; Association of Official Analytical Chemists: Washington, DC, USA, 1984.

23 Greene, J.L.; Bovell-Benjamin, A.C. Macroscopic and sensory evaluation of bread supplemented with sweet potato flour. J. Food Sci. 2004, 69, S167-S173.

24 Lawless, H.; Heymann, H. Sensory Evaluation of Food-Principles and Practices; Chapman \& Aspen Publishers, Inc.: Gaithersburg, MD, USA, 1999.

25 El-Khayat, G.H.; Samaan, J.; Brennan, C.S. Evaluation of vitreous and starchy Syrian durum (Triticum durum) wheat grains: The effect of amylase content on the starch characteristics and the flour pasting properties. Starch 2003, 55, 358-365.

26 Brennan, C.S.; Samaan, J.; El-Khayat, G.H. The effect of genoptype and environmental conditions on grain physiochemical properties of Syrian durum wheat cultivars. Int. J. Food Sci. Technol. 2012, 47, 2627-2635.

27 Chapman, S.J.; Mulvaney, S.J.; Chinnaswamy, R.; Rayas-Duarte, P.; Alvin, B. Larger deformation stress relaxation and compression-recovery of gluten representing different wheat classes. J. Cereal Sci. 2012, 55, 366-372.

28 Campbell, P.J.; Wringley, C.F.; Cressey, P.J.; Slack, C.R. Statistical correlations between quality attributes and grain-protein composition for 71 hexaploid wheats used as breeding parents. Cereal Chem. 1987, 64, 293-299.

29 Marchetti, L.; Cardos, M.; Campana, L.; Ferrero, C. Effect of glutens of different quality on dough characteristics and breadmaking performance. LWT-Food Sci. Technol. 2012, 46, 224-231.

30 Moonen, J.H.E.; Scheepstra, A.; Graveland, A. Use of the SDS sedimentation test and SDS polyacrylamide gel electrophoresis for screening breeder's samples of wheat for bread-making quality. Euphytica 1982, 31, 677-690.

31 Orth, R.A.; Bushuk, W. A comparative study of the proteins of wheat of diverse baking qualities. Cereal Chem. 1972, 49, 268-275.

32 Borghi, B.; Giordani, G.; Corbenilli, M.; Vaccini, P.; Guermandi, M.; Toderi, G. Influence of crop rotation, manure and fertilizers on bread making quality of wheat (Triticum aestivum L.). Eur. J. Aronomy 1995, 4, 37-45.

33 Sapirstein, H.D.; David, P.; Preston, K.P.; Dexter, J.E. Durum wheat bread making quality: Effect of gluten strength, protein composition, semolina particle size and fermentation time. J. Cereal Sci. 2007, 45, 150-161.

(C) 2012 by the authors; licensee MDPI, Basel, Switzerland. This article is an open access article distributed under the terms and conditions of the Creative Commons Attribution license (http://creativecommons.org/licenses/by/3.0/). 